\title{
Først engasjement, så innhold
}

Bruk av serien $\mathrm{På}$ tro og Are i religionsundervisning $i$ videregående skole.

\author{
Av Audun Toft
}

Sammendrag: Artikkelen diskuterer bruken av serien På tro og Are i religionsundervisning basert på observasjoner fra et case-studie $i$ videregående skole. Fokus er på seriens episode om buddhisme. Denne episoden er kontroversiell og har blant annet blitt kritisert av Buddhistforbundet for å fremme et feilaktig og negativt bilde av buddhismen. Likevel brukes episoden omfattende i den observerte undervisningen. Artikkelen argumenterer for at seriens underholdende og engasjerende egenskaper veier tyngst som utvalgskriterier, men at loererne tar grep for å kompensere for problematisk innhold. Ved hjelp av medialiseringsteori analyserer artikkelen konsekvenser denne typen mediebruk fär for undervisning.

Nøkkelord: På tro og Are, religionsundervisning, medier, populærkultur

Audun Toft (f. 1977), førsteamanuensis i RLE ved Universitetet i Sørøst-Norge. Adr: Postboks 7053, 3007 Drammen. E-post: audun.toft@usn.no

\section{INNLEDNING}

Så langt på min religiøse reise hadde jeg vært innom fem religioner uten å bli smittet av overtro. Men det gjensto én religion, nemlig buddhismen.

På denne måten begynner Are Sende Osen, rikskjent komiker og dokumentarskaper, en episode av det populære programmet 'På tro og Are'. Serien, der den selverklærte ateisten drar for å leve sammen med ulike religiøse mennesker for å lære mer av dem, er en suksess. NRK produserte tre sesonger av På tro og Are mellom 2010 og 2017 og serien har fortsatt stor trafikk både på NRKs vanlige nett-TV og på NRK Skole ${ }^{1}$. I denne artikkelen vil jeg se nærmere på bruken av På tro og Are i religionsundervisning i videregående skole. Basert på observasjoner fra et feltarbeid i skoleåret 2015 / 2016 diskuterer artikkelen læreres begrunnelser for å bruke serien i undervisning og hvordan denne bruken påvirker undervisningen. Spesielt fokus vil ligge på episoden som tar for seg buddhisme, en episode som har vært sterkt omdiskutert, og blant annet blitt utsatt for sterk kritikk fra norske buddhister (Buddhistforbundet, 2019). Artikkelen argumenterer for at det primært er seriens underholdningsaspekter som ligger til grunn for bruk i klasserommet. Med utgangspunkt i medialiseringsteori vil jeg vise at det kan stilles noen grunnleggende spørsmål knyttet til medienes rolle som leverandør av informasjon

1 NRK Skole er en tjeneste rettet mot lærere i den norske skolen, og tilbyr lydklipp og videoer fra NRKs arkiver med fjernsyns- og radiomateriale (se under).

Prismet - IKO-Forlaget 2020

Tilgjengelig på https://journals.uio.no/index.php/prismet. Publisert under CC BY-NC 4.0. Fagfellevurdert

Årgang 72, hefte 1, s. 23-37

ISSN: 0032-8847, ISSN online:2535-311x 
om religion. NRK retter bevisst innhold mot skolen, men dette stoffet vil også være preget av andre hensyn enn faglig etterrettelighet. Dette krever en større mediebevissthet blant lærere som bruker dette stoffet $\mathrm{i}$ undervisning.

\section{EMPIRISK MATERIALE}

Det empiriske materialet til artikkelen er hentet fra en case-studie av mediebruk i faget religion og etikk på en videregående skole på Østlandet. Dette faget er lagt $\mathrm{i}$ tredjeåret og er obligatorisk for alle i studieforberedende programmer. Faget fokuserer på kunnskap om religioner, filosofi og etikk, og betegnes også i læreplanen som et holdningsdannende fag som skal gi «respekt for ulike religiøse, livssynsmessige og etiske ståsteder» (Utdanningsdirektoratet 2006, s. 1). I løpet av skoleåret 2015/16 fulgte vi ${ }^{2}$ seks lærere og åtte klasser gjennom femti bolker på mellom én og tre skoletimer. Skolen ble valgt strategisk etter størrelse og sammensetning. Kriteriene for utvalg var at skolen skulle være stor nok til å ha flere parallelle klasser i religion og etikk og at elevgruppen ikke skulle ligge i én av ytterkantene når det kom til sammensetning av kulturell og religiøs bakgrunn (se Toft, 2019, s. 41). Datamaterialet består av håndskrevne feltnotater fra direkte observasjon av timene, transkriberte intervjuer med seks lærere og ni elever, innsamlet undervisningsmateriale fra timene, samt notater fra uformelle møter og samtaler med lærere utenfor undervisning. Det ble ikke tatt opptak av undervisning. Alle elevene var fylt, eller fylte, 18 år i observasjonsperioden.

\section{Bruken aV P̊ tro og Are}

I feltarbeidet ble vi tidlig slått av to aspekter ved bruken av På tro og Are. Det første var hvor ofte ulike episoder av denne serien ble brukt i undervisning. Det andre var at mange av elevene konsekvent rapporterte at de hadde sett episodene før. Vi fikk gjennomgående en forståelse av at mange, kanskje også et flertall, av elevene hadde sett flere episoder i religionsundervisningen i grunnskolen.

\section{Observasjon 22.10.2015}

Therese $3^{3}$ : Nå etterpå har jeg tenkt at vi skal se på et program. Jeg har vært litt usikker på om vi skal gjøre det, men jeg gjør det nå.

Gutt: På tro og Are?

Therese: På tro og Are, ja. Har dere sett før?

Jente: Masse!

Flere elever: Ja

Therese: Har dere det?

Flere elever: Ja

Gutt: Den om buddhisme. Og den hvor han besøker en muslimsk familie.

2 Feltarbeidet ble utført av Liv Ingeborg Lied og Audun Toft.

3 Navnene er endret av anonymiseringshensyn. 
Therese: Har dere sett den i et annet fag?

Jente: Nei, jeg har sett den to ganger.

Therese: På ungdomsskolen? Ja. Da er det såpass lenge siden at det $\mathrm{i}$ hvert fall ikke skader å se den igjen.

Observasjonen illustrerer dette poenget godt. Elevene er godt kjent med serien og de kjenner den fra religionsundervisning. I dette eksempelet er det verdt å merke seg at Therese, på tross av at hun har vært i tvil om hun skal bruke episoden og at så mange har sett den fra før, likevel forsvarer å bruke den som planlagt. Dette vil jeg komme tilbake til senere.

Observasjonene viser en omfattende bruk av På tro og Are. I løpet av femti bolker observerte vi serien i bruk direkte åtte ganger. Intervjuer og samtaler med lærerne bekrefter det store omfanget og viser at flere episoder fra serien ble brukt enn disse. Dette er ikke spesielt for skoleåret som ble observert. Alle lærerne bekrefter at de har brukt episoder fra serien i undervisning tidligere og at de sannsynligvis vil fortsette med dette.

\section{Intervju med Hege}

Intervjuer: Kan du si litt om bruken av på Tro og Are?

Hege: Ja. Jeg synes han er litt artig. Han fremstiller religion på en litt sånn humoristisk måte. Og det tenker jeg treffer elevene, og at han kan snakke om en del sånne fordomsfulle saker på en litt morsom måte. Og det giør det litt lettere å ta opp ting i etterkant.

Intervjuer: Hvilke episoder bruker du?

Hege: Først og fremst bruker jeg buddhisme og islam. Og da jeg var vikar i Kims klasse så brukte jeg faktisk jødedommen fordi hun synes at den passet bra inn, men jeg rakk ikke det i mine klasser.

Det er episodene om islam og buddhisme som brukes mest, men vi finner også at episodene om kristendom og jødedom brukes, om enn i noe mindre grad. En så omfattende bruk av en enkelt serie i undervisningen er i seg selv et interessant funn. Selv om det ikke er mulig å generalisere fra en enkelt case-studie som dette, så er det flere indikatorer på at andre skoler også bruker serien i utstrakt grad. NRK selv rapporterer at nett-trafikken knyttet til dette programmet er veldig omfattende i skoletiden og de tolker egne data om bruk i den retning at programmet brukes flittig i undervisning (NRK, 2019). Erfaringer fra undervisning i lærerutdanning peker også på at serien er godt kjent av studenter fra egen skolegang og fra praksis 4 .

4 At serien fremdeles brukes omfattende i undervisning støttes av en pågående (upublisert) studie av religion og etikkundervisning under nedstengingen av skoler i mars 2020 utført av Kristine Toft Rosland og undertegnede. Åtte av ni intervjuede lærere oppga i 2020 at de ofte brukte serien i undervisning. 


\section{Artikkelens målsetning}

Det er likevel ikke omfanget som er i fokus i denne artikkelen. Derimot vil jeg analysere kriteriene som legges til grunn når lærerne velger å bruke undervisningstid på denne typen mediemateriale. I en tidligere artikkel har Liv Ingeborg Lied og undertegnede pekt på at mediemateriale ofte velges ut fra underholdningsegenskaper fremfor faglig innhold i et mediemettet klasserom (Lied \& Toft, 2018). Her vil jeg vise at denne vektleggingen av underholdningsverdi får omfattende betydning for undervisningen. Dette vil jeg gjøre gjennom å ta for meg bruken av en spesifikk episode av På tro og Are der han besøker en buddhistisk familie i Trondheim. Denne episoden er av spesiell interesse fordi lærerne i mitt materiale ser denne episoden som faglig problematisk, men de velger likevel å bruke den. Med dette som utgangspunkt vil jeg peke på noen viktige aspekter ved å bruke mediemateriale som utgangspunkt for undervisning.

\section{OM MEDIER}

Ulike medier har de siste årene vokst frem som viktige kilder for kunnskap om religion i Skandinavia (Lundby \& Gresaker, 2015; Lundby m.fl., 2018). Mens tradisjonelle aktører som hjemmet og religiøse institusjoner blir mindre viktige, viser flere undersøkelser at medier som TV og aviser er stedene flest oppgir at de møter spørsmålet om religion i hverdagen. Når mediene blir de viktigste kildene til informasjon om religion, så får dette også konsekvenser for hvilken informasjon som formidles (Hjarvard, 2008). Flere studier av religion i mediene viser at det er systematiske mønstre for hva slags stoff som velges for formidling, og hvordan dette stoffet presenteres (Døving \& Kraft, 2013; Lundby m.fl., 2018). Disse mønstrene finnes på tvers av ulike medieorganisasjoner og publikasjoner. En nøkkel til å forstå samspillet mellom systematiske mønstre og variasjon er å finne i et institusjonelt perspektiv på mediene, noe som blant annet er gjort innen forskning på nyhetsmedier. Siden årtusenskiftet har mange nyhetsforskere forsøkt å forklare de store likhetene i nyhetssaker gjennom nyinstitusjonalistisk teori (Cook 1998; 2006). Ved å se utover redaksjonelle vurderinger innad i den enkelte nyhetsorganisasjon, peker de på at (nyhets) mediene må sees på som en samfunnsinstitusjon der det utvikles felles oppfatninger og normer for hva som kan regnes for god praksis, det March and Olsen kaller 'logics of appropriateness' (2004). Et slikt perspektiv peker på at den enkelte journalist (og redaksjon) forholder seg til normer og standarder som har utviklet seg over tid og inkluderer mer enn bare «rent journalistiske» prioriteringer (Allern, 2001). Spørsmål om samfunnsmandat, sjangerkrav, målgruppe, etablerte journalistiske normer og etikk vil for eksempel også ta hensyn til faktorer som føringer fra eiersiden ${ }^{5}$, økonomi og salgbarhet. Mange av disse faktorene vil opprettholdes og håndheves på tvers av den enkelte

5 Selv om norske medier har et tydelig redaktøransvar der eier ikke kan overstyre redaktøren, vil organisasjonens profil legge noen føringer på hva som presenteres og formen det får. 
organisasjon, gjennom markedsmekanismer, gjennom presseetiske kontrollmekanismer eller gjennom priser og bransjearrangementer der det utvikles felles normer for god praksis for å nevne noen. Resultatet er at det utvikles en felles forståelse av god mediepraksis på tvers av den enkelte organisasjon.

Dette påvirker innholdet som formidles. Atheide og Snow pekte alt i 1979 på at om du skal forstå mediene som innholdsleverandør, må du forstå hvordan innholdet hele tiden velges og presenteres ut fra vurderinger som er særegne for det enkelte mediet. Dette betyr at innhold som presenteres gjennom mediene i stor grad formes basert på vurderinger knyttet til mediets sjanger, format, modalitet og formål samtidig som det opprettholdes, reproduseres og reguleres i et større institusjonelt felt. Deres begrep for å operasjonalisere dette er medielogikk (media logic), et begrep som på tross av å ha blitt kritisert for å være unyansert, og for at det ikke er mulig å finne én helhetlig medielogikk (Lundby, 2009), har blitt videreutviklet som begrep for å forstå vurderingene som ligger bak utvalg og presentasjon av innhold (se Thimm m.fl., 2018).

Etter hvert som medier ${ }^{6}$ inntar en stadig større plass i norske klasserom, blir det derfor viktig å undersøke i hvilken grad dette kan medføre at medienes logikk og mønstre for representasjon av religion tas inn $\mathrm{i}$ undervisningen. I denne sammenhengen blir NRKs rolle som innholdsleverandør i norsk skole spesielt interessant. NRK er i en særstilling som en ikke-kommersiell aktør som har et samfunnsmandat for folkeopplysning, og samtidig er en produsent og tilbyder av innhold i konkurranse med kommersielle aktører i det åpne mediemarkedet. NRKs vedtekter fastslår at de «skal bidra til utdanning og læring, herunder tilby innhold tilrettelagt for skoleverket» (§43). Dette ivaretas særskilt gjennom tjenesten NRK Skole, som beskrives på egne nettsider som dette:

NRK Skole er et digitalt klipparkiv som består av lydklipp og videoer fra NRKs radioog fjernsynsarkiv, samt våre egne produksjoner. Innholdet er tilrettelagt for elever og larere i grunnskole og videregående opplaering, og er knyttet opp mot kompetansemålene i Udirs loereplandatabase. (NRK, 2018).

NRK Skole knytter altså klippene direkte mot læreplanmålene i ulike fag, blant dem KRLE og religion og etikk ${ }^{7}$. Tjenesten tilbyr, i tråd med NRKs mandat, gratis strømming av innhold, noe som innebærer at de er en lett tilgjengelig ressurs for lærere og elever. NRK oppgir selv at tjenesten er rettet mot lærere, og ikke mot elever. Selv om NRK Skole produserer noe materiale selv, er de fleste ressursene

6 Medier inkluderer i denne sammenhengen både medieteknologi, plattformer, medieprodukter og diskurser (se Lied \& Toft, 2018).

7 Tjenesten organiserer materialet overordnet ut fra skolefag, og videre inn etter kompetansemål fra det enkelte fags læreplan. I skrivende stund revideres NRK Skole i tråd med nye læreplaner, men den opprinnelige organiseringen etter forhenværende planer (som materialet til denne artikkelen forholder seg til) er fremdeles mulig å velge på tjenestens nettsider. 
hentet fra andre deler av NRKs virksomhet og er derfor ikke produsert spesifikt med tanke på undervisning.

På tro og Are - episoden om buddhisme

Artikkelens fokus er på serien På tro og Ares episode om buddhisme. Denne episoden har vært omstridt siden den kom ut i 2010. Det norske buddhistforbundet klaget den inn for Pressens faglige utvalg (PFU) i 2011 blant annet fordi NRK «gjennom usanne og nedsettende påstander sprer fordommer om en minoritetsgruppe i Norge» (Buddhistforbundet, 2011). I PFU ble NRK frikjent og utvalget uttaler følgende:

(H)umor og sative er ytringsformer som må ha en sterkere beskyttelse enn vanlig nyhets- og kommentarjournalistikk. Selv om det påklagede programmet ikke er et rent humorprogram, er det en blanding av informasjon og underholdning, og utvalget vil mene at det innklagede programmet må vurderes ut fra sin form, intensjon og tone.

(PFU, 2011)

NRK har mottatt over 500 individuelle klager på episoden og i mars 2019 ble den tematisert i kringkastingsrådet, på grunnlag av en ny klage fra buddhistforbundet på at episoden promoteres som relevant lærestoff for religionsundervisning på NRK Skoles nettsider (NRK, 2019). I kringkastingsrådets møte redegjorde NRK Skole for hvilke rutiner de har for utvalg på sine nettsider:

Da er det sånn at det NRK Skoleredaksjonen egentlig gjør kun to ting. Det er å vurdere hvorvidt dette klippet er egnet for undervisning. Og herunder selvfolgelig også da $i$ hvilke aldersgrupper det er egnet for undervisning. Og er det relevant for minst ett loeringsmål $i$ skolen? Også ligger ofte det redaksjonelle arbeidet, den journalistiske bakgrunnen, alt det der, sikringen av innholdet ligger jo ofte $i$ en annen redaksjon. Så er det rom for alt fra tørre fakta til humor, subjektive programmer og klipp, objektive programmer og klipp. Dette er jo direkte rettet mot loerere som har hoy fagkompetanse og som kan sette ting $i$ kontekst. Hvis elevene hadde vart målgruppa for NRK Skole, så hadde vi nok tenkt litt annerledes. (NRK, 2019, 49:22 - 50:17)

På tross av at episoden er kontroversiell, brukes den altså omfattende i den observerte religionsundervisningen. Jeg vil komme tilbake til hva slags vurderinger lærerne i mitt materiale gjorde. Mitt anliggende her er å vise til at serien, i likhet med andre medieproduksjoner, gjør profesjonelle valg som direkte påvirker utvalg og presentasjon av innhold. Selv om serien har dokumentariske og undervisningsrelaterte trekk, så er det andre ting som legger de største føringene på hva seerne får presentert. En omfattende analyse av episoden faller utenfor rammene av denne 
artikkelen, men jeg vil trekke frem to grunnleggende grep som gjøres i episoden.

Episodene i serien følger i hovedsak ett gjennomgående narrativ. Are har på forhånd forestillinger om de han skal besøke, men gjennom et personlig møte blir disse forestillingene justert. I episoden om islam er det forestillingene om muslimer som vestens fiende som innleder episoden, men etter å ha fastet sammen med familien Selaihi innser han at muslimer er vanlige, hyggelige mennesker. Denne reisen fra førforståelse til erfaring fungerer strukturerende for episodens innhold og styrer utvalget av det som vises. I episoden om buddhismen besøker Are familien Duong. Are møter familien med en forestilling om at buddhister er gjennomgående snille og vennlige, men tidlig i episoden kommer han i prat om forestillingen om karma. Døtrene i familien forteller ham at det å bli gjenfødt som mann er bedre enn å bli født som kvinne. Are reagerer på dette og fortsetter å undersøke karma gjennom hele episoden. Han blir gradvis mer og mer skeptisk til buddhismens lære. Etter at han har snakket med en buddhistmunk som bekrefter synet på kvinners karma, ender episoden med at Are oppsummerer:

\section{Oppholdet mitt sammen med buddhistene hadde ikke blitt helt som jeg håpet. De var utrolig vennlige og likandes folk, men når det kom til troen deres, var jeg ikke imponert. A si at noen som har det feelt kan takke seg selv fordi de har gjort noe galt $i$ et tidligere liv, det faller på sin egen urimelighet. Jeg mener det jeg, at vi skal ikke fokusere på det forrige livet og ikke det neste livet. Men det livet vi lever her og nå.}

Det andre grepet som er gjennomgående er den humoristiske vinklingen i programmet. Are Sende Osen er kjent som humorist og serien er preget av hans særegne humor. Episoden om buddhisme er ikke noe unntak. Are peker ut ting som virker fremmed og kommenterer for eksempel at klærne han har under en seremoni i tempelet ligner en pysjamas, at tempelet i seg selv ligner en kinarestaurant («Jeg skal ha fire vårruller og en chop suey») og at ritualet han fikk være med på ikke engasjerte: («for å være en good sport så skvettet jeg litt vann på Buddha-pjokken lell»). Mest fremtredende er nok likevel hvordan humor blandes sammen med fakta-stoff. Underveis i episoden brytes Ares besøk opp to ganger av små klipp som skal vise a) grunnleggende fakta om buddhisme og b) kvinnesynet i buddhismen. Innholdet som formidles, illustreres ved hjelp av tegnede animasjoner. Disse er gjennomgående humoristiske. Siddharta fremstilles som smilende, liten og tykk, kles opp i supermanndrakt og fremstilles som furtende når han må la kvinner få bli nonner. Samtalene i episoden er også preget av humor og godt humør, noe som gjør at mange av formuleringene underveis preges av at de er sagt i en humoristisk kontekst.

Fremstillingen av buddhismen i negativt og latterliggiørende lys, ser dermed ut til å følge direkte fra grep som gjør dette til et engasjerende og underholdende 
program for seeren. At Are oppriktig reagerte på det han hørte om karma, virker åpenbart. Men når dette blir valgt som problemstillingen hele episoden struktureres etter, så får det store konsekvenser for det endelige innholdet når episoden klippes, redigeres og ferdigstilles av profesjonelle aktører. Resultatet er et morsomt og tankevekkende program, men like fullt et program der underholdningsverdi og et konsistent narrativ er førende for innholdet.

\section{EPISODEN I KLASSEROMMET}

Denne episoden ble altså mye brukt $\mathrm{i}$ vårt materiale. Vi observerte tre hele opplegg der denne episoden inngikk. Jeg velger å beskrive ett av disse i detalj, men diskusjonen er basert på analyse av alle tre.

\section{Observasjon av Thereses klasse 22.10.2019}

Thereses klasse nærmer seg slutten av buddhismen og Therese har tenkt å bruke denne bolken på tre timer til å dekke de to siste kompetansemålene. «Det som er viktigst i dag er at vi får sett på det med kjønn og kjønnsroller», sier hun. «Og i læreplanen så står det faktisk at dere skal kunne drøfte syn på kjønn og kjønnsroller». Hun har laget et opplegg som tar utgangspunkt i buddhismeepisoden av På tro og Are og de går rett i gang med filmen etter en liten utveksling rundt serien (se s. 1). Thereses opplegg baserer seg på først å se episoden og diskutere den generelt i klassen. Etter dette skal elevene lese en medietekst som problematiserer episoden og blant annet inneholder utdrag fra Det norske buddhistforbundets kritikk før de fortsetter diskusjonen. Therese deltar selv aktivt i diskusjonen og kommuniserer flere ganger til klassen at det hun vil de skal sitte igjen med etter timen er at det de buddhistiske jentene sier ikke nødvendigvis er representativt for buddhister generelt og at det oftest er flere meninger innenfor en religion. Hele opplegget tar til sammen 1 time og 25 minutter. Therese avrunder med å spørre: «Klarer dere nå å si noe om kjønn og kjønnsroller på torsdag?» (som er dagen de skal ha prøve om buddhismen).

Dette er et interessant eksempel på hvordan et medieprodukt brukes i religionsundervisning. Episoden om buddhismen velges ut og transformeres til et pedagogisk artefakt som danner utgangspunkt for et større didaktisk opplegg. Det er verdt å merke seg at Therese strukturerer hele dette didaktiske opplegget etter kompetansemålet «drøfte religionens syn på kjønn og kjønnsroller» (Utdanningsdirektoratet, 2006, s. 5). Ved å velge en video som eksplisitt omhandler dette temaet ${ }^{8}$ og som samtidig vekker engasjement og underholder, lager Therese et opplegg som aktivt inviterer elevene til drøfting. Ved å bruke debatten som har rast rundt denne episoden legger også Therese opp til videre å nyansere synspunktene som kommer frem. Opplegget ga rikelig med tid for samtale og involverte en

8 Og også aktivt promoteres på bakgrunn av dette på NRK Skole. 
majoritet av elevene i plenumsdiskusjonen. På denne måten kan denne observasjonen fungere som et godt eksempel på hvordan profesjonelle lærere velger ut mediemateriale og kontekstualiserer dem inn i en faglig sammenheng, akkurat på den måten NRK Skole forutsetter. En nærmere analyse av materialet viser likevel at det er mer komplisert enn dette.

\section{Utvalgskriterier}

Som sitatet innledningsvis illustrerer, er det seriens underholdende og engasjerende egenskaper som er den primære grunnen til at serien blir brukt $\mathrm{i}$ undervisning. At serien er populær blant elevene bekreftes gjennom klasseromsobservasjonene. Elevene er gjennomgående positive til å se denne serien og uttrykker dette tydelig. Underveis i visningen av ulike episoder følger elevene godt med og det er mange tilfeller av latter underveis. Serien fungerer på samme tid som belønning og som et effektivt middel til å holde på oppmerksomhet (se også Lied \& Toft, 2018).

Dette underholdningskriteriet er så sterkt at det fremdeles er relevant når det faglige innholdet er problematisk. Alle seks lærerne i mitt materiale ser på episoden om buddhisme som potensielt problematisk. Som Geir forteller, er det sannsynlig at elevene etter episoden sitter igjen med inntrykket av at buddhismen er kvinneundertrykkende. Denne bekymringen deles av de andre og Therese bekrefter at elevene «husker den veldig godt. Det med kvinnesyn. De sitter på en måte igjen med at kvinner er dårligere enn menn». På tross av dette velger tre av lærerne å bruke episoden dette semesteret, mens to andre sier de ville ha brukt den om de hadde hatt tid nok ${ }^{9}$. Og tidsbruk er helt sentralt. På tvers av intervjuene formidles det helt tydelig at denne episoden ikke kan vises uten at det settes av god tid til å diskutere innholdet. Ragnhild redegjør for vurderingen sin på denne måten:

Det er både gode argumenter for å bruke den og mot å bruke den. De gode argumentene for er at det er jo en morsom form han har. Så den vekker litt engasjement. Også er det litt kontroversielle ting der, så det vekker i hvert fall også litt folelser i elevene. De har lyst til å diskutere ting. Det er bra. Samtidig er film et veldig sterkt medium og så har man veldig få timer til rådighet til å prove å få formidlet noe kjernestoff om hva buddhismen er. Og da er det jo litt synd om noen bare husker at buddhisme var veldig kvinneundertrykkende og hvis du er handicapet så er det fordi du har dårlig karma også. Det er liksom de tingene du sitter igjen med (...) Det krever jo at man har en ordentlig diskusjon etterpå da. Men fortsatt så kan jeg voere litt bekymret for at det er liksom det som sitter igjen. Ja. Også blir det et veldig sånn forenklet bilde av, av buddhismen da. (Intervju Ragnhild).

9 Geir valgte aktivt ikke å bruke den dette skoleåret, fordi han synes innholdet var for problematisk. Likevel har han brukt den tidligere, og dette året brukte han episodene om kristendommen, islam og jødedommen i sine timer. 
Dette sitatet illustrerer hvordan lærerne veier utvalgskriteriene opp mot hverandre. Episodens underholdende og engasjerende kvaliteter veier ikke opp for de problematiske sidene, men vektes likevel så tungt at det er verdt å arbeide den inn i et større didaktisk opplegg. Denne bruken fordrer at læreren aktivt utarbeider opplegget på en slik måte at de problematiske sidene nyanseres, eller til og med brukes som utgangspunkt for å få en bedre forståelse av spørsmål knyttet til representativitet når det kommer til representasjoner av religion. Det er likevel tydelig at vurderingen ikke er uproblematisk og er kilde til noe tvil hos lærerne.

Huff, det som er, vet du, er at det er litt fristende å bruke noe som engasjerer litt, som gir dem noen konkrete bilder og litt sånn ordentlig liv på en måte. Så det er på en måte noe som gjor at jeg er litt fristet til å bruke den, da. Men jeg synes den krever, den krever jo at vi jobber med det at alle ikke representerer andre og at ting er mer nyansert enn som så. (Intervju Therese).

\section{Konsekvenser for undervisningen}

Vi ser at lærerne kritisk vurderer episoden og tar grep for å transformere den til et pedagogisk artefakt som fremmer fagets målsetninger. Ved å anlegge et medialiseringsperspektiv på materialet trer det likevel frem noen sider som er verdt å se nærmere på. I følge medialiseringsteori er mediene en viktig aktør for samfunnsendring. Etter hvert som ulike samfunnssektorer blir avhengige av medier i sitt daglige virke, endres praksis i disse sektorene. Mediene er mer enn redskaper. De kan også sees på som en egen samfunnsinstitusjon med sine egne logikker (se ovenfor). Etterhvert som ulike medier blir en stadig viktigere del av undervisningen i den norske skolen blir det viktig å spørre seg om dette også endrer selve undervisningen på et grunnleggende nivå. Institusjonell medialiseringsteori peker på to sammenvevde måter en slik mediepåvirket endring kan skje: Gjennom overlappende institusjonelle logikker (Hjarvard, 2016) og gjennom introduksjonen av mediedynamikker i ulike institusjonelle praksiser (Hjarvard \& Lundby, 2018). Som vi har sett er medienes institusjonelle logikker en viktig del av hvordan et medieprodukt som På tro og Are produseres. Sjangermessige grep knyttet til humor, underholdning og sammenhengende narrativ styrer utvalg og presentasjon av innhold. Akkurat denne serien preges også av en sjangermessig blanding der programlederens subjektive meninger, opplevelser og humoristiske betraktninger veksler med egne 'faktasnutter' der tilsynelatende objektive fakta presenteres for seeren. Det er derimot tydelig at dette ikke er to adskilte deler av programmet, da også faktasnuttene preges av humor og innhold spesifikt valgt ut og presentert for å støtte oppunder programlederens narrativ.

Religionsundervisning som institusjonell praksis har sine egne logikker, som innebærer mer enn rene spørsmål om innholdet i undervisningen. Spørsmål knyttet 
til lovverk og læreplaner, til stoffutvalg og undervisningsmetoder og til religionsfaglige vurderinger må sees sammen med spørsmål knyttet til for tidsrammer, klassemiljø, fysiske egenskaper ved klasserommet, kjedsomhet og individuelle behov hos elevene. Disse logikkene er i utgangspunktet svært annerledes fra praksisene som styrer mediefremstillinger. I det mediemettede klasserommet finner vi likevel tendenser til overlappende logikker. Dette innebærer altså ikke nødvendigvis at religionsundervisningen blir likere medienes fremstillinger, men at dynamikker og praksiser fra medieinstitusjonene introduseres i undervisningen der de virker sammen med eksisterende dynamikker og endrer forholdene for undervisning. Utstrakt mediebruk i klasserommet kan for eksempel aksentuere og forsterke allerede eksisterende klasseromsdynamikker knyttet til kjedsomhet og kamp om elevenes oppmerksomhet og dette kan føre til en sterk vektlegging av underholdende, kontroversielle og engasjerende egenskaper når didaktiske opplegg utformes (se Lied og Toft, 2018). Mediemateriale som er spesifikt produsert med tanke på disse egenskapene kan dermed fremstå som velegnet, også, som vi har sett, når det faglige innholdet er problematisk. Det er viktig å se at denne typen endringer i religionsundervisning oppstår i religionslærerens egen praksis, gjennom at de didaktiske vurderingene også inkluderer mediedynamikker.

Materialet denne artikkelen bygger på gir et konkret eksempel på en slik endring av religionsundervisning. Det er den aktuelle episodens underholdende og engasjerende kvaliteter som veier tyngst som utvalgskriterier, under forutsetning av at den brukes i et gjennomarbeidet didaktisk opplegg. Dette valget gir konsekvenser for undervisningen, men disse er ikke bare et resultat av føringer i programmet. Konsekvensene er i stor grad et resultat av institusjonelle vurderinger spesifikke for religionsundervisning. I dette tilfellet er dette blant annet a) behovet for å holde på elevenes oppmerksomhet overordnet, men spiller sammen med andre sentrale vurderinger som b) sterkt fokus på kompetansemål, c) begrenset tid, d) behovet for et forsvarlig faglig innhold og e) ansvaret for å motvirke fordommer og negative forestillinger. Det endelige undervisningsopplegget er dermed et resultat av en prosess som både inkluderer føringer fra episoden og profesjonelle religionsdidaktiske vurderinger. Dette får konsekvenser for undervisningen.

Det er særlig tre konsekvenser jeg vil trekke frem her: i) Episoden setter premissene for hele undervisningen rundt ett kompetansemål, ii) episodens fortolkningsrammer overtas av lærere og elever, og iii) episoden bruker stereotypiske og eksotiserende elementer som ikke blir tematisert i etterkant.

i) Episoden strukturerer og setter premissene for hele undervisningen om kjønn og kjønnsroller

Ved å velge episoden som inngangsvinkel for å nå kompetansemålet «drøfte 
religionens [buddhismens] syn på kjønn og kjønnsroller» (Utdanningsdirektoratet, 2006, s. 6), ekskluderes andre innfallsvinkler. Episoden er egnet for å underholde og engasjere, mens innholdet er så problematisk at det ikke kan brukes alene. I dette tilfellet innebærer valget at a) hele den tilgjengelige tiden satt av til dette kompetansemålet brukes på et opplegg sentrert rundt denne ene episoden og b) episoden blir primærkilde og referansepunkt for hele opplegget. Det er lite rom for å trekke inn elementer som ikke allerede er tatt opp i episoden. Bruken av episoden innebærer dermed store begrensninger for hvordan et stort tema som kjønn og kjønnsroller i buddhismen tematiseres.

\section{ii) Episodens fortolkningsrammer danner grunnlaget for den faglige diskusjonen}

Den andre konsekvensen jeg vil trekke frem er at episodens fortolkningsrammer overtas i klasserommet. Med fortolkningsrammer, eller framing (Entman, 1993), mener jeg her føringene som legges på hvordan vi skal forstå det vi ser ${ }^{10}$. Særlig gjelder dette hvordan intervjuobjektenes uttalelser om forskjellen på kvinner og menn kan tolkes. I episoden legges det sterke føringer som skal sørge for at seeren skjønner at uttalelsene betyr at buddhismen har et problematisk syn på kvinner. Jentene sier blant annet, i en lattermild tone, at «kvinnene lettere blir sur, og så fær de å gnæg, gnæg hele tida, mens mannfolk så er det sånn at blir du sur, så snakk ut og that's it» og at kvinner blir gravide og har «humørsvingninger hver måned». Det er disse uttalelsene som danner grunnlaget for episodens kritiske blikk på karma og kvinnesyn i buddhismen, og gjennomgående inviteres seeren til å tolke dem som et symptom på noe veldig problematisk. Dette er ikke i seg selv en urimelig tolkning, jentene sier dette som en forklaring på at kvinner har dårligere karma enn menn. Likevel introduserer produksjonen et forsterkende element. Uttalelsene om kvinner er ikke i seg selv spesielt mye mer dramatiske enn hva man hører om forskjeller på kvinner og menn i et livsstilsmagasin, en TV-serie eller i dagligdagse samtaler. Men i denne episoden settes uttalelsene inn $\mathrm{i}$ tolkningsrammer om kvinnefiendtlige religiøse praksiser, og blandes sammen med sterkere uttalelser i seriens 'faktadel' om at Buddha mente «kvinner var mentalt underlegne menn». Gjennomgående i de observerte klasseromsdiskusjonene ble denne tolkningsrammen overtatt. Fokuset lå hele tiden på hvorvidt disse kvinnefiendtlige uttalelsene var representative, ikke på hvor kvinnefiendtlige de egentlig var. Dette illustreres gjennom uttalelser som at «de har et feil syn på likestilling», som en gutt sier det. Eller som en jente utdyper: «De skjønner ikke at de kan gjøre samme jobb som menn». I det observerte undervisningsopplegget er det episodens fortolkningsrammer som muliggiør en drøfting av representativitet.

10 Overtakelse av medienes tolkningsrammer trekkes ofte frem som en sentral mediedynamikk der mediene påvirker andre samfunnsområder, blant annet gjennom at spesifikke representasjoner, fremstillinger og dramaturgi 'følger med’ når ulike fenomener tematiseres (Hjarvard \& Lundby, 2018, s. 56 - 58). 
iii) eksotisering og stereotyper importeres, men tematiseres ikke

Noe av det første vi lærer bort til kommende religionslærere er at vi bør unngå å fokusere på det som fremstår som eksotisk og fremmed, eller på underholdende stereotyper, på tross av at dette er en takknemlig måte å skape interesse på (se Sødal, 2009, 109ff; Andreassen, 2016, 132). Dette begrunnes religionsdidaktisk med at slike fremstillinger bryter med fagets målsetninger gjennom å aksentuere det sære og fremmede ved religiøse mennesker. Denne vurderingen deles ikke nødvendigvis av medieprodusenter, noe som kommer tydelig frem i denne episoden av På tro og Are. Episoden bruker nettopp det eksotiske og stereotypiske aktivt for å underholde. Som den lattermilde seansen der den asiatiske familien synger karaoke, eller de mange fleipete kommentarene knyttet opp til fremmed religiøs praksis som bønn før reisen eller ritualet for å feire Siddhartas fødsel. Disse elementene må derfor sees som helt sentrale deler av hvorfor episoden er morsom. Men, i ingen av de tre klasseromsdiskusjonene vi observerte ble dette tematisert. Fokus er på det store spørsmålet om hvor vidt de som intervjues kan sies å være representative for buddhisters syn på kvinner generelt, mens de produksjonsmessige grepene som skaper underholdning ved hjelp av stereotypiske fremstillinger passerer under radaren.

\section{KonkLUSJON}

Lærerne i mitt materiale lager gode didaktiske opplegg med bakgrunn i episoden om buddhismen. Den brukes ikke ukritisk. Likevel ser vi at det primære utvalgskriteriet er seriens underholdende og engasjerende kvaliteter og at behovet for å lage et utvidet didaktisk opplegg kommer som en følge av seriens innhold. Dette innholdet er sterkt preget av logikkene som inngår i å lage en underholdningsserie. Denne artikkelen viser at dette kan ha innvirkning på hvordan sider ved religion blir undervist blant annet ved at undervisningen struktureres rundt seriens innhold og premisser, at lærere og elever overtar seriens fortolkningsrammer og at stereotype og eksotiske aspekter ved en religion fremheves.

Det kommer også frem at NRK Skole har en spesiell rolle. Gjennom å bevisst rette innhold inn mot skole og tilby dette gratis som en del av sitt samfunnsmandat, vil NRK fremstå som en saklig, sikker og tilgjengelig leverandør av undervisningsmateriale. Det er derfor viktig å ta høyde for at den største delen av ressursene som deles ikke er produsert i undervisningshensikt, men av andre redaksjoner som følger sine egne standarder for utvalg og presentasjon av ulikt stoff. Når NRK Skole aktivt promoterer et stort utvalg av ressurser fra ulike sjangere og redaksjoner som direkte skolerelevant, glir NRKs rolle som folkeopplysningsaktør og underholdningstilbyder over i hverandre. Videre forskning på NRK Skoles rolle i den norske skolen vil derfor være av stor interesse.

Ny teknologi gir nye forutsetninger for undervisning, og jo enklere det er 
å ta i bruk verktøy og produkter fra ulike sammenhenger, jo viktigere blir det å reflektere over hvordan disse påvirker det som læres. Ulike medieløsninger gir fantastiske muligheter for spennende læring, men det krever også at didaktikken oppdateres fortløpende i takt med den teknologiske utviklingen.

\section{LitTERATUR}

Allern, Sigurd (2001, August). Journalistiske og kommersielle nyhetsverdier: nyhetsbedrifter som institusjonsforvaltere og markedsaktører. I $15^{\text {th }}$ Nordic Conference of Media and Communication Research, Reykjavik (Iceland) (Vol. 13).

Altheide, David L. \& Snow, Robert P. (1979). Media logic. Beverly Hills, CA: Sage. Andreassen, Bengt-Ove (2016). Religionsdidaktikk : En innføring (2. utg.). Oslo: Universitetsforlaget.

Buddhistforbundet (2011). Brev_til_NRK_-_03_01_11_klage.doc. Hentet fra https://buddhistforbundet.no/wp-content/uploads/2020/02/1101031.pdf, lørdag 21.03.2020

Buddhistforbundet (2019). Buddhistforbundet klager på bruk av program om buddhisme. Hentet fra https://buddhistforbundet.no/kringkastingsradet-190307, fredag 20.03.2020.

Cook, Timothy E. (1998). Governing with the news: The news media as a political institution. Chicago: University of Chicago Press.

Cook, Timothy E. (2006). The News Media as a Political Institution: Looking Backward and Looking Forward. Political Communication, 23(2), 159-171.

Døving, Cora Alexa \& Kraft, Siv Ellen (2013). Religion $i$ pressen. Oslo: Universitetsforlaget.

Entman, Robert M. (1993). Framing: Toward Clarification of a Fractured Paradigm. Journal of Communication 43 (4): 51-58.

Hjarvard, Stig (2008). The Mediatization of Religion. A Theory of the Media as Agents of Religious Change. Northern Lights, vol. 6, Bristol: Intellect Press.

Hjarvard, Stig (2016). Mediatization and the Changing Authority of Religion. Media, Culture \& Society, 38(1): 8-17.

Hjarvard, Stig \& Lundby, Knut (2018). Chapter 3 Understanding Media Dynamics. I Knut Lundby (red.), Contesting Religion: The Media Dynamics of Cultural Conflicts in Scandinavia. Berlin, Boston: De Gruyter.

Lied, Liv Ingeborg \& Toft, Audun (2018). 'Let Me Entertain You.' Media Dynamics in Public Schools. I Knut Lundby (red.). Contesting Religion: The Media Dynamics of Cultural Conflicts in Scandinavia. Boston: De Gruyter.

Lundby, Knut \& Gresaker, Ann Kristin (2015). Religion i mediene - omstridt og oversett? I Inger Furseth (red.). Religionens tilbakekomst i offentligheten?: Religion, politikk, medier, stat og sivilsamfunn i Norge siden 1980-tallet. Oslo: Universitetsforlaget. 
Lundby Knut, Reintoft Christensen, Henrik, Gresaker, Ann Kristin, Lövheim, Mia, Niemelä, Kati. \& Sjö, Sofia - med Moberg, Markus. \& Daníelsson, Árni Svanur (2018). Religion and the Media: Continuity, Complexity, and Mediatization. I Inger Furseth (red.). Religious Complexity in the Public Sphere: Comparing Nordic Countries. Basingstoke: Palgrave MacMillian.

March, James G. \& Olsen, Johan P. (2004). The logic of appropriateness, ARENA Working Papers no. 04/09. Oslo: ARENA, Centre for European Studies.

NRK (2018). Om NRK Skole. Hentet fra https://www.nrk.no/skole/om-nrkskole-1.12568596, lørdag 21.03.2020.

NRK. (2019). 7. mars 2019 - Kringkastingsrådet 2019. Hentet fra https://tv.nrk. no/serie/kringkastingsraadet/201903/AINF00000219/avspiller, fredag 20.03.2020.

PFU (2011). Buddhistforbundet v. forstander Egil Lothe mot NRK. PFU-sak 025/11. Hentet fra https://presse.no/pfu-sak/02511/, lørdag 21.03.2020

Thimm, Caja, Anastasiadis, Mario \& Einspänner-Pflock, Jessica (red.). (2018). Media logic(s) revisited: Modelling the interplay between media institutions, media technology and societal change (Transforming communications: studies in crossmedia research). Basingstoke: Palgrave Macmillan.

Toft, Audun (2019). Conflict and Entertainment: Media Influence on Religious Education in Upper Secondary School in Norway. Doktorgradsavhandling. MF Vitenskapelig Høgskole, Oslo.

Utdanningsdirektoratet (2006) [RE06]. Læreplan for Religion og etikk. Fellesfag $i$ studieforberedende utdanningsprogram. Oslo: Utdanningsdirektoratet. 